\title{
Community Structure of South American Carnivores in the Past and Present
}

\author{
Francisco J. Prevosti • Javier A. Pereira
}

Published online: 31 August 2014

(C) Springer Science+Business Media New York 2014

Understanding the causes that structure natural communities has long been an important goal for biologists. The question of what regulates the distribution and abundance of species in communities is central because it connects widespread processes (e.g., competition, predation), historical effects, and the interactions of these competing mechanisms with the mixture dependent on the habitats and organisms involved. Carnivores (mammals with a carnivorous diet), particularly, play a crucial role in maintaining the structure and stability of communities through predation, competition, or by altering prey behavior and prey habitat selection. For this reason, they have been used as a model to understand the effects of competition or top-down control in community structure. Although carnivores are naturally rare, due to their position at the top of the food web, their removal can have a variety of cascading effects within the community (Ripple et al. 2013).

Current diversity of South American terrestrial carnivorans (mammals of the Order Carnivora) is relatively high, with 40 out of 245 species (ca. 16\%) of the order occurring in this subcontinent (Hunter 2011). But the geological record shows that a rich diversity of meat-eaters also inhabited South America in the past (Prevosti and Soibelzon 2012). During the lower-middle Miocene, carnivores from this part of the world were mainly represented by some groups of didelphimorphian marsupials and the extinct metatherian

\section{F. J. Prevosti $(\bowtie) \cdot J$. A. Pereira}

División Mastozoología, Museo Argentino de Ciencias Naturales, "Bernardino Rivadavia"-CONICET, Av. Ángel Gallardo 470,

C1405DJR Buenos Aires, Argentina

e-mail: protocyon@hotmail.com

J. A. Pereira

e-mail: javipereira@yahoo.com

F. J. Prevosti

Departamento de Ciencias Básicas, Universidad Nacional de Luján, Luján, Buenos Aires, Argentina clade Sparassodonta, and carnivorans only migrated to South America starting in the late Miocene (Marshall 1978; Prevosti and Soibelzon 2012; Prevosti et al. 2013). Although interesting advances regarding community structure of modern South American carnivores have been made during the last decades (see below), knowledge about the structure of historical assemblages is still poor. Determining the structure and dynamics of present and past food webs will be useful to gain insight into the forces that model carnivoran communities.

In November 2012, aimed at updating the state of knowledge about this topic, we organized the symposium "Community structure of South American carnivores in the past and present" in Buenos Aires, Argentina, at the II Congreso Latinoamericano de Mastozoología y XXV Jornadas Argentinas de Mastozoologia. Our main idea was to discuss predator-prey relationships and carnivore community structure in different mammalian assemblages and ages, using diverse study approaches to improve the understanding of the ecology, paleoecology, and evolution of South American carnivores. This was evident in the selection of topics covered by the contributions presented (see below), ranging from paleoecology, morphology, and cranial morphometrics to trophic segregation, intraguild predation, and functional diversity of species assemblages. To contextualize this event (and this volume), we further offer a brief background highlighting the principal advances and approaches used to study structure of carnivore communities that inhabit or inhabited South America during the last 19 million years (from the late early Miocene to the present).

The structure of the carnivore communities (i.e., the degree of overlap and pattern of distribution of predator species based on body size, diet, and locomotory habits, and the inferred intraguild interactions and prey/predator relationships) of fossil assemblages of South America is scantly studied. Most paleoecological studies are limited to paleoautecological 
inferences (e.g., dietary habits), first based on the general description of bones and teeth (e.g., Lund 1839; Muñiz 1845; Marshall 1977a, 1978; Berta 1989; Cartelle and Langguth 1999) and only recently on statistical techniques (e.g., Van Valkenburgh 1991, 1999; Prevosti and Palmqvist 2001; Prevosti 2006; Soibelzon and Tartarini 2009; Figueirido and Soibelzon 2009). Similarly, paleosinecological studies, or the analysis of the structure of the carnivore communities in the past, are also very limited. Van Valkenburgh (1991; see also Van Valkenburgh 1999), using body size and craniodental indexes, generated a morphospace of the Pleistocene carnivores and suggested that the presence of several large hypercarnivore canids was related to the scarcity of other large hypercarnivores (e.g., felids). Using species frequencies in an early Pleistocene level of the Buenos Aires province (Argentina), Berman (1994) considered that the notoungulate Mesotherium, the ground sloth Scelidotherium, and the glyptodont Neosclerocalyptus were important prey of Smilodon. Later, Fariña (1996) estimated the number of species and the biomass of predators and prey in the late Pleistocene of Buenos Aires, and suggested that the community was "out of balance" because few carnivores were present in comparison to the number and biomass of large mammals and mega-mammals. The hypothesis of Fariña (1996) was further revised by Prevosti and Vizcaíno (2006), who found several biases and problems in his approach, and proposed an alternative hypothesis suggesting a more balanced scenario between carnivores and prey. They also discussed prey-predator relationships and potential intraguild interactions based on dietary habits and body size inferences for predators and potential prey species. Fariña's (1996) method was then reused by Vizcaíno et al. (2010) to propose that some of the Santa Cruz Formation (late early Miocene) mammal assemblages were out of balance, with proportionally few Sparassodonta. In the same way, Fariña et al. (2014) went further and included new Pleistocene mammal assemblages in their analysis, finding new evidence to support the scenario described in Fariña (1996). However, since Vizcaíno et al. (2010) and Fariña et al. (2014) did not correct the methodological biases and errors pointed out by Prevosti and Vizcaíno (2006), their conclusions about the faunal unbalance may not be reliable.

Predator-prey relationships for the large hypercarnivore canids of the Pleistocene (e.g., Protocyon, Theriodictis) were inferred using stable isotopes (Prevosti and Schubert 2013) or the estimated body mass of the canids and their potential prey, and the known prey/predator relationships in living carnivorans (Prevosti and Palmqvist 2001; Prevosti et al. 2009). Figueirido and Soibelzon (2009; see also Soibelzon and Schubert 2011) interpreted that the presence of several small-sized bear species with less carnivorous diet in the late Pleistocene of South America, in comparison to the only species recorded in the early-middle Pleistocene, is related to the presence of more large carnivorous species in the late Pleistocene. But available data do not support this interpretation, because early-middle Pleistocene assemblages have similar numbers of carnivorans (or large carnivorans) as the late Pleistocene (see Prevosti and Soibelzon 2012; Prevosti et al. 2013). Martin $(2008,2013)$ studied the taphonomy of late Pleistocene caves of southern Patagonia and interpreted some of them as dens of an extinct form of jaguar (Panthera onca mesembrina), which consumed camelids, horses, and ground sloths (Mylodon). Using dental indices, body size, stable isotopes, and taphonomy, Prevosti and Martin (2013) reconstructed the carnivore guild of southern Patagonia in the latest Pleistocene, and discussed potential prey/predator relationships. Soibelzon (2011), based on dental anatomy, suggested that the procyonids of the late Miocene-Pliocene (Cyonasua and Chapalmalania) had a more predatory habit than living ones, and that they became extinct because the immigration of other carnivorans to South America, as was discussed about the extinction of Chapalmalania and the immigration of bears by Kraglievich and de Olazabal (1959). But the dentition of these extinct procyonids lack functional carnassials and the development of large shearing crests typical of more predaceous carnivorans. Recently, a fused caudal vertebra of a glyptodont with bite marks was interpreted as produced by the giant procyonid Chapalmalania (de los Reyes et al. 2013). Finally, Cione et al. (2009) discussed that the extinction of large carnivores in the late Pleistocene could produce a "topdown" effect that could contribute to the extinction of large mammals and mega-mammals in South America, but the available information do not allow a test of this idea.

About older faunas, punctual evidence of one specimen of a medium-sized sparassodont (Lycopsis longirostrus) of the middle Miocene of Colombia should be mentioned, because it contains remains of a rodent (Scleromys colombianus) (Marshall 1977b). Croft (2001, 2006; see also Wroe et al. 2004; Vizcaíno et al. 2010) using xenograms, prey-predators richness relationships, and abundance of predators of the Cenozoic ages of South America, concluded that prePleistocene faunas have low numbers of predators. Prevosti et al. (2012), based on new collections, published information, and in that moment ongoing paleoecological works on sparassodonts (Argot 2004; Ercoli and Prevosti 2011; Ercoli et al. 2012), revised the diversity and structure of mammalian predators of the Santa Cruz Formation (late early Miocene). They found a high diversity of predators (11 species of sparassodonts) that fall in the range of modern communities, and a good separation of sparassodont taxa based on the combination of body size, diet, and locomotory habits, but they did not use statistical methods to evaluate this segregation. Finally, the hypothesis of a competitive replacement of sparassodonts by carnivorans was evaluated by Prevosti et al. (2013) using richness curves of these groups along time, diet, and body size inferences to evaluate the 
existence of temporal and ecological overlap between them. They found some temporal but no ecological overlap, and interpreted that environmental changes could be the cause of the extinction of Sparassodonta. Recently, Engelman and Croft (2014) discussed the possibility that the rise of large carnivorous didelphoid marsupials during the late MiocenePliocene and the first record of a large procyonid in the "middle" Pliocene could be related to the extinction of small carnivorous and large omnivorous sparassodonts, respectively (see also Goin and Pardiñas 1996; Prevosti et al. 2013; Zimicz this volume).

Changing the focus toward modern carnivores, the number of publications regarding aspects of community structure has increased notably in the past two decades. First, several articles have analyzed the degree to which the niches of sympatric species overlap, considering the dietary habits (e.g., Johnson and Franklin 1994a; Farrell et al. 2000; Walker et al. 2007; Zapata et al. 2007; Bianchi et al. 2013), microhabitat use (e.g., Sollmann et al. 2012), or activity patterns (e.g., Di Bitetti et al. 2009; Lucherini et al. 2009; Romero-Muñoz et al. 2010). Other authors performed studies considering two or three niche dimensions simultaneously (i.e., diet, space, and time), addressing complete assemblages or particular dyads in canids (e.g., Johnson and Franklin 1994b; Jiménez et al. 1996; Juarez and Marinho-Filho 2002; Jácomo et al. 2004; Vieira and Port 2007) and felids (e.g., Scognamillo et al. 2003; Di Bitetti et al. 2010). Further, since the ecological overlap among species can differ under anthropogenic or natural disturbances, the effects of different human activities (e.g., introduced species [Polisar et al. 2003; Novaro et al. 2000; Palacios et al. 2012; Valenzuela et al. 2013], habitat modification [Lyra-Jorge et al. 2010; Andrade-Núñez and Aide 2010; Lantschner et al. 2012]) or natural phenomena (e.g., "El Niño Southern Oscillation" [Jaksic et al. 1997], increased flooding [Canepuccia et al. 2008]) on the community structure has been revised. Local differences in abundances or density of sympatric carnivores were also evaluated (e.g., Pereira et al. 2011; Kasper et al. 2012).

Behavioral interactions among carnivores were also studied in South American carnivore communities. Donadio and Buskirk (2006) explored the influence of body size, diet, predatory habits, and taxonomic relatedness on interspecific killing, employing data that included several species from this subcontinent. Hunter and Caro (2008) also assessed the potential for interspecific competition and predation within the assemblage of mammalian carnivorans in the Americas, and their continental-scale approach captured the diversity of potential killing interactions within a large set of carnivorans, including 77 species with different degrees of phylogenetic relatedness and variation in range overlap. Other publications have focused on particular groups; for example, Di Bitetti et al. (2010) studied niche partitioning and species coexistence in a felid assemblage, generating hypotheses about behavioral differences that may facilitate species coexistence, whereas Oliveira et al. (2010) proposed the "Ocelot effect" (i.e., the ocelot Leopardus pardalis restricts the success of other minor felid populations) as a mechanism of determining the dynamics of the mesopredator community in Neotropical forests.

Morphology of South American modern carnivorans was also the center of attention, assuming that niche relationships of species in a community are reflected in their morphological adaptations. Zapata et al. (2008) used an ecomorphological approach to examine trophic diversity in the terrestrial carnivore assemblage from the Argentinean Patagonia, by selecting measures related with the shape and size of carnivoran mandibles and teeth. They found that species grouped in the morphospace in four morphoguilds, following a carnivoryomnivory-insectivory/herbivory gradient. While carnivorans with a specialized dental pattern for consumption of meat (i.e., felids and mustelids) cluster in one of the extremes of the morphospace and species with specialized dental patterns for grinding invertebrates and vegetal materials (i.e., mustelids) score in the opposite side, the species with generalized dental patterns (i.e., canids) scatter in the center. On the other hand, Morales and Giannini (2010) studied the Neotropical felid assemblage on the basis of craniodental variables reflecting morphofunctional variation, adding to their analysis factors such as phylogenetic covariation, geographical distribution, habitat use, and activity patterns. They found that the species tend to segregate in morphospace plus one or more factors (e.g., habits) that make interspecific overlap in niche space minimal. They also reconstructed the historical assembly of the Neotropical felid guild on the basis of dated phylogenies, biogeographic history, and the fossil record, finding a pattern of successive invasions and speciation in which new lineages occupied previously vacant areas of morphospace, or new species occupied overlapping areas but with contrasting habits.

Finally, robust data on the ecology and life-history traits (e.g., reproductive lifespan, number and size of offspring) are still needed for most Neotropical carnivorans. Since communities usually include a mix of species having different evolutionary relationships, life-history traits and strategies can differ dramatically among sympatric taxa. As a result of this data gap, our knowledge about South American carnivorans is largely partial, and important hypotheses about community structure remain virtually untested.

In this context, the aim of our symposia was to act as a catalyst for researchers interested in structure of carnivore communities. The seven contributions compiled in this volume cover a wide range of approaches, taxonomic groups (Carnivora, Sparassodonta, Didelphimorphia), and ages. These papers are complementary to previous contributions or go beyond, bringing interesting synthesis or unexplored new research lines. 
First, Ercoli, Prevosti, and Forasiepi studied the community structure of carnivores of the Santa Cruz Formation (late early Miocene). Based on body size, diet (derived from a dental index), and locomotion (from a morphogeometric study of limb bones), these authors evaluated through statistical techniques the existence of segregation between sparassodont species, testing if they have a random, systematic, or aggregated pattern. They found that the distribution of species in the morphospace delimited by the mentioned variables is systematic, indicating the presence of good separation among predators and minimizing competition. They also evaluated potential predator-prey links using body mass information of sparassodonts, and potential and the known predator-prey body mass relationships. They also discussed the existence of competence between Sparassodonta and the "terror birds" (Phorusrhacidae).

Zimicz studied the change in diversity, body size, and diet of carnivorous Didelphimorphian in the late Miocene-Pliocene, and its correlation with small-sized sparassodonts (Hathliacyniidae) diversity, to explore the existence of a competitive replacement of small sparassodonts by didelphimorphians. She found some overlap in size, but not in dental index (and in the multivariate space) between them, and concluded that they use different ecological "space" and that the extinction of the Hathliacyniidae was probably related to environmental changes.

Morales and Giannini's work is a bridge between paleontological and neontological studies, because it explores changes in the Neotropical felid assemblage since the late Pleistocene extinction. They used cranial and skeletal measurements, multivariate techniques, and phylogenetic comparative methods to analyze a possible segregation of felids in the present and in the Pleistocene, trying to identify if phylogeny, size, or functional aspects explain the distribution of felids in the morphospace. They stated that size was the principal factor that structured the ensemble, but that the phylogeny has also affected the pattern of distribution in the assemblage. On the other hand, Schiaffini and Prevosti present a similar work focused on the living small carnivorans of southern South America, using geometric morphometics instead of "traditional" methods. Phylogenetic relationships explained a large part of the structure of this guild, but size, diet, and habitats also contributed to separate species.

Zapata, Delibes, Travaini, and Procopio performed an interesting study that also is a bridge, but in this case between morphological and ecological approaches. They studied the diet and morphometric indexes of some carnivorans of Patagonia and found a good correspondence in one season (spring-summer) but not in the other (fall-winter). This work showed that at fine scales (e.g., annual variation) morphology could not correctly reconstruct prey-predator relationships, but at a larger scale there is a good correlation between morphology and diet as was reported by other authors (e.g., Van Valkenburgh 1988, 1989; Palmqvist et al. 1999; Friscia et al. 2007).

Oliveira and Pereira evaluated the role of intraguild predation and interspecific killing as structuring forces of carnivoran communities in South America. They found that the hypercarnivorous jaguars, pumas, and ocelots are the species most likely to have significant impact on the guild, and suggested that intraguild predation and interspecific killing are not random and reflect widespread interactions that influence carnivoran community structure.

Finally, Farías and Svensson assessed the vulnerability of the functional richness of South American carnivoran assemblages, both at continental and regional levels. They assessed through simulations the form of the association between functional richness and species richness, finding low functional redundancy and high sensitivity to global extinctions. The authors suggested the existence of non-compensatory responses to environmental stressors by functionally redundant species and, thus, sensitivity of carnivoran functional richness to ongoing trends in land conversion and habitat degradation. On the other hand, they observed that functional richness at regional scale paralleled latitudinal gradients in species richness, but vulnerability did not entirely match these variables in space, nor did it risk estimates that accounted for regions' conservation status.

Acknowledgments To the organization committee of the "II Congreso Latinoamericano de Mastozoología y XXV Jornadas Argentinas de Mastozoologia" for allowing us to organize this symposium and to CONICET for financial support. John R. Wible and several reviewers provided valuable help during the organization of this volume. Thanks to all the authors and colleagues involved in this symposium for their support, patience, and enthusiasm.

\section{References}

Andrade-Núñez MJ, Aide TM (2010) Effects of habitat and landscape characteristics on medium and large mammal species richness and composition in northern Uruguay. Zoologia (Curitiba) 27:909-917

Argot C (2004) Evolution of South American mammalian predators (Borhyaenoidea): anatomical and palaeobiological implications. Zool J Linn Soc 140:487-521

Berman WD (1994) Los Carnívoros Continentales (MammaliaCarnivora) del Cenozoico en la Provincia de Buenos Aires. PhD thesis, Universidad Nacional de La Plata, La Plata, 413 pp

Berta A (1989) Quaternary evolution and biogeography of the large South American Canidae (Mammalia: Carnivora). Univ Calif Publ Geol Sci 132:1-149

Bianchi RC, Campos RC, Xavier-Filho NL, Olifiers N, Gompper ME, Mourao G (2013) Intraspecific, interspecific, and seasonal differences in the diet of three mid-sized carnivores in a large Neotropical wetland. Acta Theriol 59:13-23

Canepuccia AD, Farias AA, Escalante AH, Iribarne O, Novaro A, Isacch JP (2008) Differential responses of marsh predators to rainfallinduced habitat loss and subsequent variations in prey availability. Can J Zool 86:407-418 
Cartelle C, Langguth A (1999) Protocyon troglodytes (Lund): Um canídeo intertropical extinto. An Acad Bras Cienc 71:371-384

Cione AL, Tonni EP, Soibelzon LH (2009) Did humans cause the late Pleistocene-early Holocene mammalian extinctions in South America in a context of shrinking open areas? In: Haynes G (ed) American Megafaunal Extinctions at the End of the Pleistocene. Springer Science, Dordrecht, pp 125-144

Croft DA (2001) Cenozoic environmental change in South America as indicated by mammalian body size distributions (cenograms). Divers Distrib 2:271-287

Croft DA (2006) Do marsupials make good predators? Insights from predator-prey diversity ratios. Evol Ecol Res 8:1193-1214

de los Reyes M, Poiré D, Soibelzon L, Zurita AE, Arrouy MJ (2013) First evidence of scavenging of a glyptodont (Mammalia, Glyptodontidae) from the Pliocene of the Pampean region (Argentina): taphonomic and paleoecological remarks. Palaeontol Electron 16:1-13

Di Bitetti MS, De Angelo CD, Di Blanco YE, Paviolo A (2010) Niche partitioning and species coexistence in a Neotropical felid assemblage. Acta Oecol 36:403-412

Di Bitetti MS, Di Blanco YE, Pereira JA, Paviolo A, Jiménez Pérez I (2009) Time partitioning favors the coexistence of sympatric crabeating foxes (Cerdocyon thous) and pampas foxes (Lycalopex gymnocercus). J Mammal 90:479-490

Donadio E, Buskirk SW (2006) Diet, morphology, and interspecific killing in Carnivora. Am Naturalist 167:524-536

Engelman RK, Croft DA (2014). A new species of small-bodied sparassodont (Mammalia, Metatheria) from the middle Miocene locality of Quebrada Honda, Bolivia. J Vertebr Paleontol 34:672688

Ercoli D, Prevosti FJ (2011) Estimación de masa de las especies de Sparassodonta (Mammalia, Metatheria) de edad Santacrucense (Mioceno temprano) a partir del tamaño del centroide de los elementos apendiculares: inferencias paleoecológicas. Ameghiniana 48:462-479

Ercoli MD, Prevosti FJ, Álvarez A (2012) Form and function within a phylogenetic framework: locomotory habits of extant predators and some Miocene Sparassodonta (Metatheria). Zool J Linn Soc 165: 224-251

Fariña RA (1996) Trophic relationship among Lujanian mammals. Evol Theor 11:125-134

Fariña RA, Czerwonogora ADA, Giacomo MDI (2014) Splendid oddness: revisiting the curious trophic relationships of South American Pleistocene mammals and their abundance. An Acad Bras Cienc 86: 311-331

Farrell LE, Roman J, Sunquist ME (2000) Dietary separation of sympatric carnivores identified by molecular analysis of scats. Mol Ecol 9: $1583-1590$

Figueirido B, Soibelzon LH (2009) Inferring palaeoecology in extinct tremarctine bears (Carnivora, Ursidae) using geometric morphometrics. Lethaia 43:209-222

Friscia AR, Van Valkenburgh B, Biknevicius AR (2007) An ecomorphological analysis of extant small carnivorans. J Zool (London) 272:82-100

Goin FJ, Pardiñas, UFJ (1996). Revisión de las especies del género Hyperdidelphys Ameghino, 1904 (Mammalia, Marsupialia, Didelphidae). Su significación filogenética, estratigráfica y adaptativa en el Neógeno del Cono Sur sudamericano. Estud geol Madr 52:327-359

Hunter J, Caro T (2008) Interspecific competition and predation in American carnivore families. Ethol Ecol Evol 20:295-324

Hunter L (2011) Carnivores of the World. Princeton University Press, Princeton

Jácomo ATA, Silveira L, Diniz-Filho JAF (2004) Niche separation between the maned wolf Chrysocyon brachyurus, the crab-eating fox Dusicyon thous and the hoary fox Dusicyon vetulus in central Brazil. J Zool (London) 262:99-106
Jaksic EM, Meserve PL, Gutierres JR (1997) A long-term study of vertebrate predator response to an El Niño (ENSO) disturbance in western South America. Oikos 78:341-354

Jiménez JE, Yáñez JL, Tabilo EL, Jaksic FM (1996) Nichecomplementarity of South American foxes: reanalysis and test of a hypothesis. Rev Chil Hist Nat 69:113-123

Johnson EW, Franklin WL (1994a) The role of body size on the diets of sympatric grey and culpeo foxes. J Mammal 75:163-174

Johnson EW, Franklin WL (1994b) Spatial resource partitioning by sympatric grey fox (Dusicyon griseus) and culpeo fox (Dusicyon culpaeus) in southern Chile. Can J Zool 72:1788-1793

Juarez KM, Marinho-Filho J (2002) Diet, habitat use, and home ranges of sympatric canids in central Brazil. J Mammal 83:925-933

Kasper CB, Bastazini VAG, Soares JBG, de Freitas TRO (2012) Abundance of Conepatus chinga (Carnivora, Mephitidae) and other medium-sized mammals in grasslands of southern Brazil. Iheringia, Ser Zool (Porto Alegre) 102:303-310

Kraglievich JL, de Olazabal AG (1959) Los prociónidos extinguidos del género Chapalmalania Ameghino. Rev Mus Argent Cienc Nat (Cienc zool) 6:1-59

Lantschner MV, Rusch V, Hayes JP (2012) Habitat use by carnivores at different spatial scales in a plantation forest landscape in Patagonia, Argentina. Forest Ecol Manage 269:271-278

Lucherini M, Reppucci JI, Walker RS, Villalba ML, Wurstten A, Gallardo G, Iriarte A, Villalobos R, Perovic P (2009) Activity pattern segregation of carnivores in the high Andes. J Mammal 90:1404-1409

Lund PW (1839) Blik paa Brasiliens Dyreverden för Sidste Jordomvaeltning. Anden Afhandling: Pattedyrene. Det kongelige Danske Vindenskabernes Selskabs naturvidenskabelige og mathematiske Afhandliger 8:61-144

Lyra-Jorge MC, Ribeiro MC, Ciocheti G, Tambosi LR, Pivello VR (2010) Influence of multi-scale landscape structure on the occurrence of carnivorous mammals in a human-modified savanna, Brazil. Eur J Wildl Res 56:359-368

Marshall LG (1977a) Evolution of the carnivorous adaptative zone in South America. In: Hecht MK, Goody PC, Hecht BM (eds) Major Patterns in Vertebrate Evolution. Plenum Press, New York, pp 709 722

Marshall LG (1977b) A new species of Lycopsis (Borhyaenidae: Marsupialia) from the La Venta fauna (late Miocene) of Colombia, South America. J Paleontol 51:633-642

Marshall LG (1978) Evolution of the Borhyaenidae, extinct South American predaceous marsupials. Univ Calif Publ Geol Sci 117: $1-89$

Martin FM (2008) Bone crunching felids at the end of the Pleistocene in Fuego - Patagonia, Chile. J Taph 6:337-372

Martin FM (2013) Tafonomía y paleoecología de la transición Pleistoceno-Holoceno en Tierra del Fuego-Patagonia. Interacción entre poblaciones humanas y de Carnívoros y su importancia como agentes en la formación del registro fósil. Universidad de Magallanes, Punta Arenas

Morales MM, Giannini NP (2010) Morphofunctional patterns in Neotropical felids: species co-existence and historical assembly. Biol J Linn Soc 100:711-724

Muñiz FJ (1845) Descripción del Munifelis bonaerensis. Gaceta Mercantil 6603:1-2

Novaro AJ, Funes MC, Walker RS (2000) Ecological extinction of native prey of a carnivore assemblage in Argentine Patagonia. Biol Conserv 92:25-33

Oliveira TG, Tortato MA, Silveira L, Kasper CB, Mazim FD, Lucherini M, Jácomo AT, Soares JBG, Marques RV, Sunquist ME (2010) Ocelot ecology and its effect on the small-felid guild in the lowland Neotropics In: Macdonald DW, Loveridge AJ (eds) Biology and Conservation of Wild Felids. Oxford University Press, Oxford, pp $563-574$ 
Palacios R, Walker RS, Novaro AJ (2012) Differences in diet and trophic interactions of Patagonian carnivores between areas with mostly native or exotic prey. Mammal Biol 77:183-189

Palmqvist P, Arribas A, Martínez-Navarro B (1999) Ecomorphological analysis of large canids from the lower Pleistocene of southeastern Spain. Lethaia 32:75-88

Pereira JA, Di Bitetti MS, Fracassi NG, Paviolo A, De Angelo CD, Di Blanco YE, Novaro AJ (2011) Population density of Geoffroy's cat in scrublands of central Argentina. J Zool (London) 283:37-44

Polisar J, Maxit I, Scognamillo D, Farrell L, Sunquist ME, Eisenberg JF (2003) Jaguars, pumas, their prey base, and cattle ranching: ecological interpretations of a management problem. Biol Conserv 109: 297-310

Prevosti FJ (2006) Grandes cánidos (Carnivora, Canidae) del Cuaternario de la Republica Argentina: sistemática, filogenia, bioestratigrafiay paleoecología. PhD thesis, Universidad Nacional de La Plata, La Plata, $506 \mathrm{pp}$

Prevosti FJ, Forasiepi AM, Ercoli MD, Turazzini GF (2012) Paleoecology of the mammalian carnivores of the Santa Cruz Formation (late early Miocene). In: Vizcaíno SF, Kay RF, Bargo MS (eds) Early Miocene Paleobiology in Patagonia: High Latitude Paleocommunities of the Santa Cruz Formation. University Chicago Press, Chicago, pp 173-193

Prevosti FJ, Forasiepi AM, Zimicz N (2013) The evolution of the Cenozoic terrestrial mammalian predator guild in South America: competition or replacement? J Mammal Evol 20:3-21

Prevosti FJ, Martin FM (2013) Paleoecology of the mammalian predator guild of the southern Patagonia during the latest Pleistocene: ecomorphology, stable isotopes, and taphonomy. Quaternary Internatl 305:74-84

Prevosti FJ, Palmqvist P (2001) Análisis ecomorfológico del canido hipercarnívoro Theriodictis platensis (Mammalia Carnívora) del Pleistoceno de Sudamérica. Ameghiniana 38:375-384

Prevosti FJ, Schubert B (2013) First taxon date and stable isotopes $(\mathrm{C}, \mathrm{N})$ for the large hypercarnivorous South American canid Protocyon troglodytes (Canidae, Carnivora). Quaternary Internatl 305:67-73

Prevosti FJ, Soibelzon LH (2012) The evolution of South American carnivore fauna: a paleontological perspective. In: Patterson B, Costa LP (eds) Historical Biogeography of Neotropical Mammals. University Chicago Press, Chicago, pp 102-122

Prevosti FJ, Vizcaíno S (2006) The carnivore guild of the late Pleistocene of Argentina: paleoecology and carnivore richness. Acta Palaeontol Pol 51:407-422

Prevosti FJ, Ubilla M, Perea D (2009) Large extinct canids from the Pleistocene of Uruguay: systematic, biogeographic, and paleoecological remarks. Hist Biol 21:79-89

Ripple WJ, Estes JA, Beschta RL, Wilmers CC, Ritchie EG, Hebblewhite M, Berger J, Elmhagen B, Letnic M, Nelson MP, Schmitz OJ, Smith DW, Wallach AD, Wirsing AJ (2013) Status and ecological effects of the world's largest carnivores. Science 343 DOI: 10.1126/science. 1241484

Romero-Muñoz A, Maffei L, Cuéllar E, Noss AJ (2010) Temporal separation between jaguar and puma in the dry forests of southern Bolivia. J Trop Ecol 26:303-311
Scognamillo D, Maxit IE, Sunquist M, Polisar J (2003) Coexistence of jaguar Panthera onca and puma Puma concolor in a mosaic landscape in the Venezuelan llanos. J Zool (London) 259:269-279

Soibelzon LH (2011) First description of milk teeth of fossil South American procyonid from the lower Chapadmalalan (late Miocene-early Pliocene) of "Farola Monte Hermoso", Argentina: paleoecological considerations. Paläont Z 85:83-89

Soibelzon LH, Schubert BW (2011) The largest known bear, Arctotherium angustidens, from the early Pleistocene Pampean Region of Argentina, with a discussion of size and diet trends in bears. J Paleontol 85:69-75

Soibelzon LH, Tartarini VB (2009) Estimación de la masa corporal de las especies de osos fósiles y actuales (Ursidae, Tremarctinae) de América del Sur. Rev Mus Argent Cienc Nat n s 11:243-254

Sollmann R, Furtado MM, Hofer H, Jácomo ATA, Tôrres NM, Silveira L (2012) Using occupancy models to investigate space partitioning between two sympatric large predators, the jaguar and puma in central Brazil. Mammal Biol 77:41-46

Valenzuela AEJ, Raya Rey A, Fasola L, Schiavini A (2013) Understanding the inter-specific dynamics of two co-existing predators in the Tierra del Fuego Archipielago: the native southern river otter and the exotic American mink. Biol Invasions 15:645-656

Van Valkenburgh B (1988) Trophic diversity within past and present guilds of large predatory mammals. Paleobiology 14:156-173

Van Valkenburgh B (1989) Carnivore dental adaptations and diet: a study of trophic diversity within guilds. In: Gittleman JL (ed) Carnivore Behavior, Ecology and Evolution. Cornell University Press, Ithaca, pp 410-436

Van Valkenburgh B (1991) Iterative evolution of hypercarnivory in canids (Mammalia: Carnivore): evolutionary interactions among sympatric predators. Paleobiology 17:340-362

Van Valkenburgh B (1999) Major patterns in the history of carnivorous mammals. Annu Rev Earth Planet Sci 27:463-493

Vieira EM, Port D (2007) Niche overlap and resource partitioning between two sympatric fox species in southern Brazil. J Zool (London) 272:57-63

Vizcaíno SF, Bargo MS, Kay RF, Fariña RA, Di Giacomo M, Perry JMG, Prevosti FJ, Toledo N, Cassini GH, Fernicola JC (2010) A baseline paleoecological study for the Santa Cruz Formation (late-early Miocene) at the Atlantic coast of Patagonia, Argentina. Palaeogeogr Palaeoclimatol Palaeoecol 292:507-519

Walker RS, Novaro AJ, Perovic P, Palacios R, Donadio E, Lucherini M, Pia M, López MS (2007) Diets of three species of Andean carnivores in high-altitude deserts of Argentina. J Mammal 88:519-525

Wroe S, Argot C, Dickman C (2004) On the rarity of big fierce carnivores and primacy of isolation and area: tracking large mammalian carnivore diversity on two isolated continents. Proc Royal Soc Lond B 271:1203-1211

Zapata SC, Travaini A, Ferreras P, Delibes M (2007) Analysis of trophic structure of two carnivore assemblages by means of guild identification. Eur J Wildl Res 53:276-286

Zapata SC, Procopio DE, Martínez-Peck R, Zanón JI, Travaini A (2008) Identificación de morfogremios como aproximación al estudio de reparto de recursos en ensambles de carnívoros terrestres. Mastozool Neotrop 15:85-101 